〔Regular paper〕

\title{
Micro-two-dimensional gel electrophoresis with agarose gel in the first dimension
}

\author{
Masamichi Oh-ishi and Tamio Hirabayashi
}

\begin{abstract}
SUMMARY
A procedure was established for micro-two-dimensional gel electrophoresis with agarose gels in the first dimension. Agarose (Agarose IEF, Pharmacia) was previously found to be suitable for the analysis of high molecular weight proteins with a wide range of isoelectric points, but rather difficult to be handled for micro-scale electrophoresis. However, addition of $1 \mathrm{M}$ thiourea in combination with $5 \mathrm{M}$ urea to the medium for agarose gel made it possible to be used with ease on micro-scale as well as on macro-scale. Since thiourea is a potent protein solubilizing reagent, almost all amounts of proteins including structural proteins were presented on the respective positions on two-dimensional gels. This method is applicable to other experiments with high molecular weight proteins to be analyzed in a wide range of isoelectric points.
\end{abstract}

Key words : two-dimensional gel electrophoresis, agarose gel, muscle protein.

\section{INTRODUCTION}

The purposes of using two-dimensional polyacrylamide gel electrophoresis are roughly classified into two types: One is to characterize a protein of concern, so as to investigate its purity, homogeneity, molecular weight and isoelectric point; the other is to separate the whole protein constituents of cells or tissues. In the former case, we can employ the best conditions for the particular protein. However, we can not choose them in the latter case in which all we can do is either to be satisfied with the methods reported already or to be involved in an endless work of improving the method.

Proteins in muscle tissue have been studied in detail in many respects, and their characteristics are well known. When we first tried to prepare a protein map of the muscle by two-dimensional gel electrophoresis with acrylamide gel in the first dimension ${ }^{1)}$ we could not find a well-known peptide, myosin heavy chain, in the two-dimensional pattern. Later, we have reported an improved method for analysis of the heavy chain and troponin complex of chicken skeletal muscle ${ }^{2)}$. However, we

1 次元目にアガロースゲルを用いたミクロ 2 次元電気泳動法

大石正道・平林民雄, 筑波大学生物科学系

Correspondence address: Tamio Hirabayashi, Institute of Biological Sciences, University of Tsukuba, Tsukuba -shi, Ibaraki 305, Japan

Abbreviation used : SDS, sodium dodecyl sulfate; TEMED, N,N, $\mathrm{N}^{\prime}, \mathrm{N}^{\prime}$-tetramethylethylenediamine.

(Received October, 29 1987, Accepted February, 10 1988) 
were still not,completely satisfied with the method, since the method as it was reported ${ }^{2}$ was not so easy for us to carry out the experiment on microscale, and some amount of myosin heavy chain was still trapped at the top of agarose gel of the first dimension. In order to improve the method further we have added $1 \mathrm{M}$ thiourea and $5 \mathrm{M}$ urea in the agarose gel medium. Thiourea has been reported to be very potent in solubilizing proteins ${ }^{3)}$ and, what is more, the incorporation of this reagent has enabled us to prepare agarose gels at room temperature and to carry out isoelectric focusing on micro-scale for two-dimensional gel electrophoresis. In this paper, we describe details of the gel preparation procedure and present a protein map of rabbit skeletal muscle (psoas) on both micro- and macro-scales to compare and evaluate the two methods.

\section{MATERIALS AND METHODS}

\section{1) Sample preparation}

Freshly obtained rabbit skeletal muscle (psoas) was cut into small blocks, wrapped with aluminum foil, and stored frozen at $-80^{\circ} \mathrm{C}$ until use. The frozen muscle piece $(0.1 \mathrm{~g})$ was minced with scissors and homogenized in $4 \mathrm{ml}$ of $8 \mathrm{M}$ guanidine- $\mathrm{HCl}$ solution containing $10 \%$ 2-mercaptoethanol, $0.01 \mathrm{M}$ sodium pyrophosphate and $0.1 \mathrm{M}$ Tris- $\mathrm{HCl}, \mathrm{pH} 7.5$, in a Dounce homogenizer. The homogenate was incubated in a water bath at $60^{\circ} \mathrm{C}$ for $3 \mathrm{~min}$. After dialysis at $0^{\circ} \mathrm{C}$ for $4 \mathrm{~h}$ against 3 changes of 20 volumes of $5 \mathrm{M}$ urea and $1 \mathrm{M}$ thiourea containing 0 . $17 \%$ 2-mercaptoethanol and $0.01 \mathrm{M}$ tetrasodium pyrophosphate, the dialyzate was centrifuged at 14,000 rpm for 15 min with a Beckman JA 14 rotor. The clear supernatant was used for the first-dimension isoelectric focusing. One part of the supernatant left over was mixed with 4 parts of $1 \%$ agarose containing $2 \%$ SDS, $10 \%$ glycerol, $5 \% 2-$ mercaptoethanol, $0.02 \%$ bromophenol blue, and $0.05 \mathrm{M}$ Tris $-\mathrm{HCl}, \mathrm{pH} 6.8$, kept in boiling water for 5 min, sucked up into a glass tube $(150 \times 2.5 \mathrm{~mm}$ i.d. $)$ and kept cold until the agarose solidified. This was used as a reference for the total muscle extract in the second-dimension SDS-polyacrylamide gel electrophoresis.

\section{2) Micro-two-dimensional gel electrophoresis}

Agarose gel in capillary tubes was prepared as follows. Agarose $(0.04 \mathrm{~g}$, Pharmacia Agarose IEF) and $\mathrm{D}$-sorbitol $(0.48 \mathrm{~g})$ were dissolved in $2 \mathrm{ml}$ of distilled water in a boiling water bath. After they were completely dissolved, a mixture of urea $(1.20 \mathrm{~g})$ and thiourea $(0.30 \mathrm{~g})$ powder was added to the hot agarose solution, and allowed to dissolve completely by shaking (Incubation of the solution in boiling water to dissolve the powder is not recommended). Once the urea and thiourea were dissolved, the agarose solution did not solidify at room temperature. Aliquots of the agarose solution, $0.3 \mathrm{ml}, 1.18$ $\mathrm{ml}$, and $0.9 \mathrm{ml}$, were transferred into separate tubes. To the first, second, and third tubes, $15 \mu 1$ of ampholyte (pH2.5-5), $12 \mu \mathrm{l}$ of ampholyte (pH3-10) together with $60 \mu \mathrm{l}$ of ampholyte (pH4-6.5), and 45 $\mu 1$ of ampholyte (pH8-10.5) from Pharmacia were added respectively, and they were referred to as acidic, neutral and basic solutions (Table 1).

For isoelectric focusing, hematocrit capillary tubes $(75 \times 1 \mathrm{~mm}$ i.d., VC-H075P, Terumo Ltd.) were used. The bottom of the tube was melted a bit on gas flame until a small hole of about half the size of the original was formed, so that the solid agarose gel will not slip out. The other side (top) of the tube was left as it was in order to take out the gel through it after focusing was completed. After the tube was marked at $18 \mathrm{~mm}, 54 \mathrm{~mm}$, and $60 \mathrm{~mm}$ from its bottom, the basic solution was introduced up to $18 \mathrm{~mm}$ from the bottom by capillary action. After wiping the tip of capillary with filter paper, the neutral solution was then introduced in the same way until the top of the solution reached $54 \mathrm{~mm}$ from the bottom, so was the acidic solution up to 60 $\mathrm{mm}$ from the bottom, leaving a $15 \mathrm{~mm}$-long empty space on the top. These operations gave an agarose column composed of acidic ( $6 \mathrm{~mm}$ long), neutral (36 $\mathrm{mm}$ long), and basic (18 $\mathrm{mm}$ long) gels. Capillary tubes thus charged with three kinds of ampholyte 
solutions were laid horizontally in a moisture chamber at $4^{\circ} \mathrm{C}$ for more than $3 \mathrm{~h}$, or preferably, overnight. Once the agarose solution has set, it never turns to sol at room temperature. A very thin capillary pipet which was made by pulling the hematocrit capillary tube on a flame was used to charge samples (about $0.5 \mu \mathrm{l}$ ) and to overlay a solution of $4 \mathrm{M}$ urea and $1 \mathrm{M}$ thiourea on the sample up to the top of the tube.

Isoelectric focusing was carried out at $4^{\circ} \mathrm{C}$ for $1 \mathrm{~h}$ at $100 \mathrm{~V}$ and then for $5.5 \mathrm{~h}$ at $200 \mathrm{~V}$, with $0.2 \mathrm{M} \mathrm{NaOH}$ in the upper reservoir $(50 \mathrm{ml})$ and $0.04 \mathrm{M} \mathrm{DL}$-aspartic acid in the lower one $(50 \mathrm{ml})$. When focusing was completed, the agarose gels were removed through the top hole of the capillary tubes by gravity or moderate pressure into a denaturing solution of 10 $\%$ trichloroacetic acid and $5 \%$ sulfosalicylic acid. After gentle agitation for $5 \mathrm{~min}$, the photograph of precipitated protein bands was taken with dark field illumination. The gel was immersed in distilled water for $30 \mathrm{sec}$, and was transferred onto the top of SDS-polyacrylamide gel for the seconddimension run. The agarose gel was settled by pouring on it a small amount of $1 \%$ agarose (Agarose I, Wako Junyaku) solution, and an SDS incubation medium of $0.125 \mathrm{M}$ Tris- $\mathrm{HCl}, \mathrm{pH} 6.8,2 \%$ SDS, $10 \%$ glycerol, $5 \%$ 2-mercaptoethanol and 0.02 $\%$ bromophenol blue was overlaid on the firstdimension agarose gel. Electrophoresis was carried out as described by Laemmli ${ }^{4}$, with a modification that $0.1 \%$ TEMED was used for polymerization of acrylamide with $12-20 \%$ gradient of concentration. The gel size was $190 \times 55 \times 0.5 \mathrm{~mm}$ which suited for accepting 3 agarose gels.

Electrophoresis was conducted for $2 \mathrm{~h}$ with a constant current of $30 \mathrm{~mA}$. The gel was stained with $0.1 \%$ Coomassie brilliant blue $\mathrm{R}$ in $50 \%$ trichloroacetic acid for $1 \mathrm{~h}$ and destained with $25 \%$ methanol and $10 \%$ acetic acid. All processes starting from isoelectric focusing could be finished in a day.

As for the gels which were visualized by silver stain, following modifications were made: The supernatant of the muscle extract was diluted 10 times with the final outer medium for dialysis, that is, $5 \mathrm{M}$ urea, $1 \mathrm{M}$ thiourea, $0.01 \mathrm{M}$ tetrasodium pyrophosphate and $0.17 \% 2$-mercaptoethanol. About 0.5 $\mu l$ of the diluted supernatant was charged onto one tube. Isoelectric focusing was carried out at $200 \mathrm{~V}$ for $2 \mathrm{~h}$ and at $400 \mathrm{~V}$ for $2 \mathrm{~h}$. The concentration of glycerol in the SDS incubation medium was reduced to $5 \%$ to prevent floating of the agarose gel which was not fixed with the agarose solution on the acrylamide gel. The concentration of 2-mercaptoethanol in the medium was also reduced to 1 $\%$, since the reagent was contaminated with something positive for silver stain which was carried out according to the method of Merril et $a l .^{5)}$ and repeated once more to get tropomyosin spots stained definitely.

\section{3) Macro-two-dimensional gel electrophoresis}

This was carried out as reported previously ${ }^{2}$ except for the following procedure:Samples and the three agarose solutions, acidic, neutral and basic, were prepared as for the micro-two dimension gel electrophoresis (Table 1). The volumes of

Table 1.Compositions of agarose gels for isoelectric focusing.

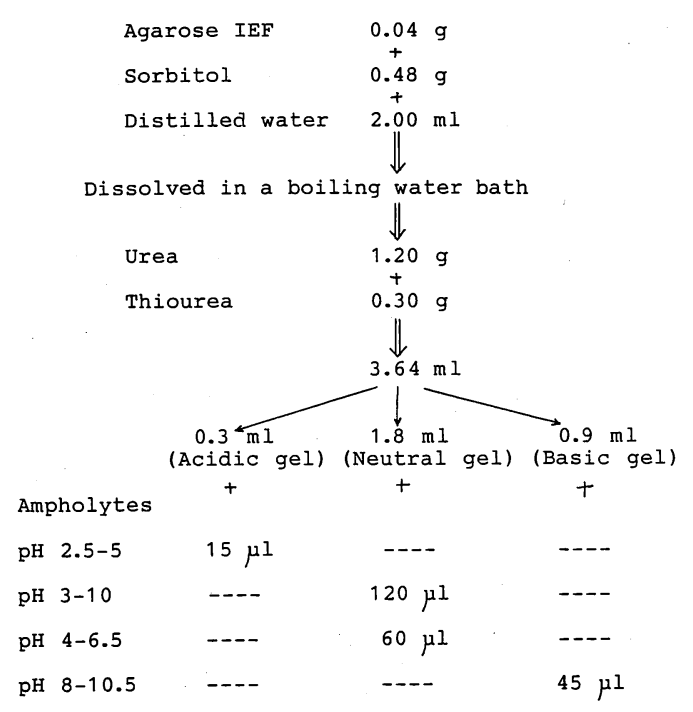


the agarose solutions were those just enough to prepare three gel columns in glass tubes $(260 \times 2.5$ $\mathrm{mm}$ i.d.). The solution of $4 \mathrm{M}$ urea and $1 \mathrm{M}$ thiourea was overlaid on the charged sample up to the top of the glass tubes.

\section{RESULTS AND DISCUSSION}

Preparation of samples for isoelectric focusing is the first important step which affects reliability of the final pattern. For homogenization of muscle tissue, we employed $8 \mathrm{M}$ guanidine- $\mathrm{HCl}$ which completely inhibited protease and other enzyme activities contained in the homogenate $e^{6)}$, and we did not employ any detergent since it did not improve sub- stantially the two-dimensional pattern of skeletal muscle proteins ${ }^{2}$. The composition of the solution for agarose gels was determined to meet two requirements ; one is to dissolve as much protein as possible, the other is to let the agarose solution set at $4^{\circ} \mathrm{C}$. It was possible to raise the concentration of urea or thiourea up to $6 \mathrm{M}$ or $1.5 \mathrm{M}$ respectively. However, these concentrations were so close to the critical conditions that we refrained from employing these concentrations. We avoided the use of SDS in the sample solutions for the first-dimension isoelectric focusing ${ }^{7}$, since we doubted if the twodimensional pattern with SDS shall give correct isoelectric point of each protein.

A trial of the macro-scale electrophoresis (Fig. 1)

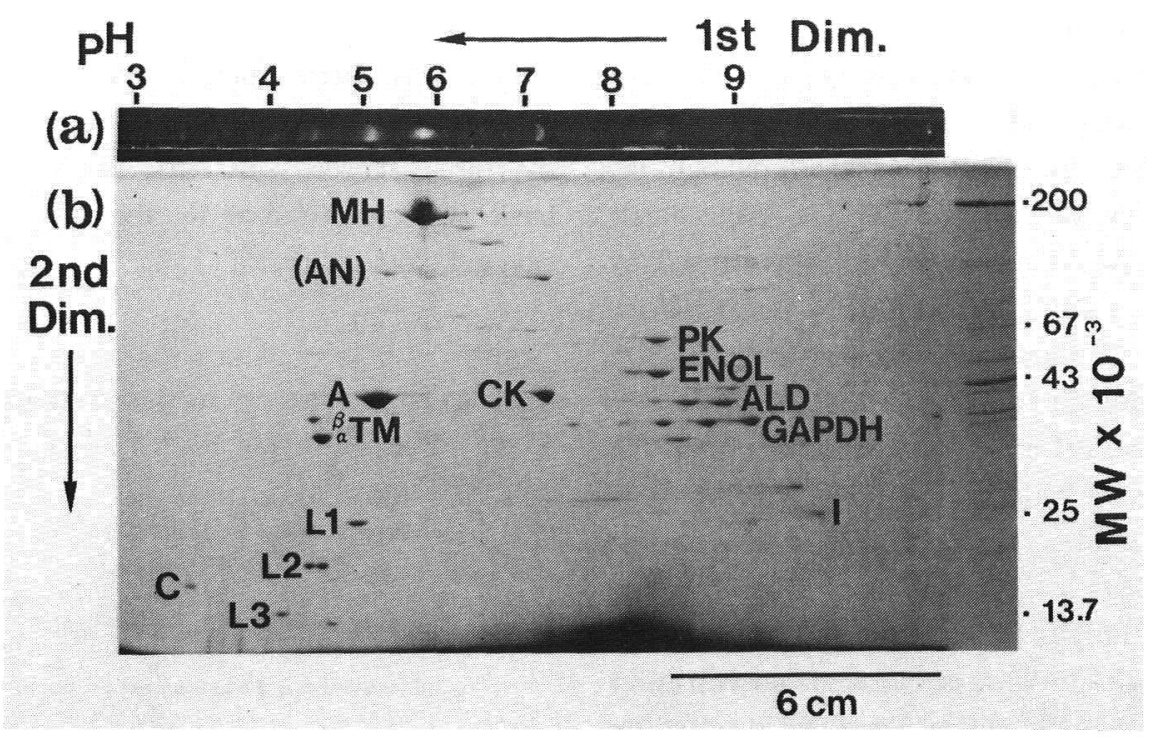

Fig. 1. Macro-two dimensional gel electrophoresis of rabbit skeletal muscle (psoas) extract.

(a) An agarose gel after the first-dimension isoelectric focusing of muscle extract in the absence of detergent. Fifteen $\mu \mathrm{l}$ of the supernatant of the muscle extract was applied to the gel prepared as described under MATERIALS AND METHODS. (b) The second-dimension SDS-polyacrylamide (12-20\% gradient) gel electrophoresis. The gel (a) was used in (b) after the photograph was taken. An agarose column containing the total muscle extract was put on the right-hand end of the polyacrylamide gel as a reference. The abscissa gives isoelectric point and the ordinate gives molecular weight $\times 10^{-3}$. Spots were marked after Giometti et al. MH, myosin heavy chain; PK, pyruvate kinase; ENOL, enolase; ALD, aldolase; CK, creatine kinase; A, actin; TM, tropomyosin; GAPDH, glyceraldehyde-3-phosphate dehydrogenase; I, troponin-I; L1-L3, myosin light chains 1-3; $\mathrm{C}$, troponin $\mathrm{C} ;(\mathrm{AN})$ is judged to be $\alpha$-actinin from the amount and position. 
of rabbit psoas proteins revealed that much more myosin heavy chain than in previous work ${ }^{2)}$ was separated by isoelectric focusing and the amounts of other high molecular weight proteins including $\alpha^{-}$ actinin increased. In other words, only a small portion of total muscle protein was left at the top of isoelectric focusing gels. This means that the optimum volume of the sample for macro-system was $15 \mu 1$ rather than $40 \mu 1$ that was used in the previous experiments $^{2}$. A wide range of isoelectric point covering from under $\mathrm{pH} 3$ to over $\mathrm{pH} 9$ is one of the advantages of this system which enables us to investigate both acidic and basic proteins on a single gel. Since the agarose solution never solidifies at room temperature, it was much easier to prepare the micro-scale agarose gel in hematocrit tubes. Fig. 2 shows one example of the micro-scale electrophoresis which was carried out with one thirtieth the amount of sample for macro-scale electrophoresis. High molecular weight peptides were seen as well separated spots around the myosin heavy chain, and almost the same range of $\mathrm{pH}$ gradient as on the macro-scale gels was formed so that many basic proteins were found on the basic side. Separation of creatine kinase, actin and tropomyosin was well comparable to that on the macro-scale gel. However, the micro-scale two-dimensional gel electrophoresis has its inherent limitation with regard to sensitivity and resolution. For example, loading a comparatively large amount of a single component usually does not give a good two-dimensional pattern. For the same reason we could not charge a

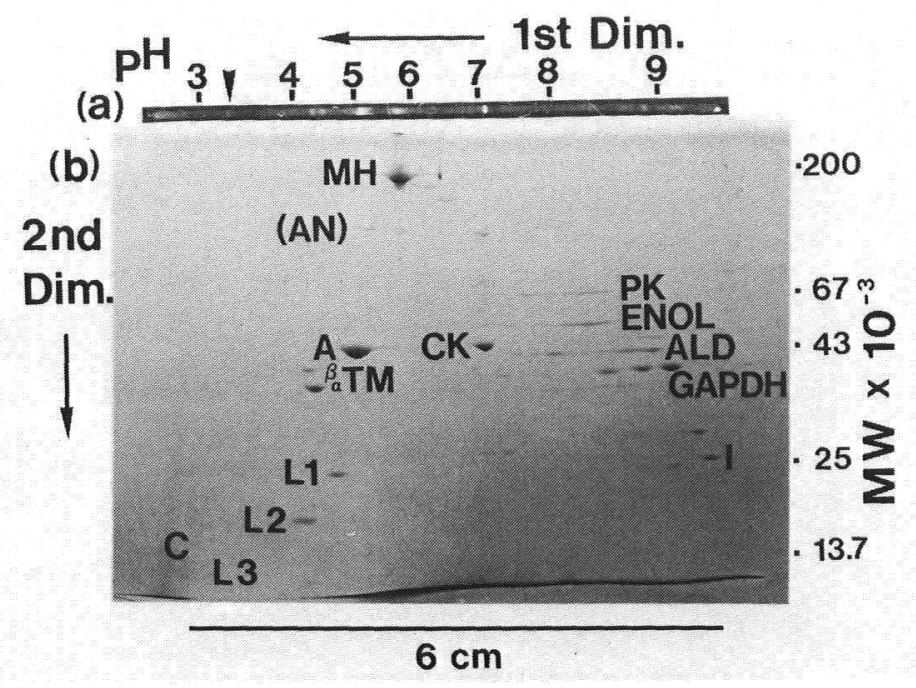

Fig. 2. Micro-two-dimensional gel electrophoresis of rabbit skeletal muscle (psoas) extract.

(a) A micro-agarose gel after the first-dimension isoelectric focusing. About $0.5 \mu 1$ of the muscle extract was charged onto the gel in a hematocrit tube, and isoelectric focusing was conducted for $1 \mathrm{~h}$ at $100 \mathrm{~V}$ and then for $5.5 \mathrm{~h}$ at $200 \mathrm{~V}$. The photograph was taken with dark-field illumination after the gel was immersed in the denaturing solution. An arrowhead shows the precipitated band of troponin C. (b) The second-dimension SDS-polyacrylamide gel electrophoresis with a $12-20 \%$ gradient micro-gel $(60 \times 55 \times 0.5$ $\mathrm{mm})$. The gel was stained with Coomassie brilliant blue. The experiment was conducted under otherwise the same conditions as in Fig. 1. 
large amount of sample onto gels to detect the faint spots of myosin light chain 3 and troponin $C$ without disturbing the spot of myosin heavy chain which tended to aggregate during isoelectric focusing. One thirtieth the amount of the sample used for the macro-scale gel was found too much for the micro -scale gel when the protein amount per unit area of cross section was compared between micro- and macro-scale gels. As for troponin $\mathrm{C}$, there was another reason that its dye-binding constant is very small, so that it could hardly be recognized on two -dimensional pattern although it could on the firstdimension agarose gel (arrowhead on the $\mathrm{pH}$ scale in Fig. 2).

In order to detect minor spots which could not be stained with Coomassie brilliant blue, we tried silver stain of the micro-gel with one tenth of the sample amount for Coomassie stain (Fig. 3). Most spots appeared almost the same as on micro-gels stained with Coomassie brilliant blue with the myosin light chain 3 clearly stained. However, the silver-staining too has some drawbacks. For one thing, the myosin heavy chain and tropomyosin, which had been focused well on their respective isoelectric points, were stained very faintly. The stain density of the latter increased only after repetition of the stain procedure once more, although the density of the former did not increase. To avoid horizontal nonspecific stain of 2-mercaptoethanol its concentration in the SDS incubation medium was reduced to $1 \%$. However, this reduction caused emergence of new spots (arrows in Fig. 3) under the actin spot and the myosin light chain 2 spot. These spots probably resulted from incomplete disruption of intramolecular disulfide bonds. At any rate, it can be concluded that the two-dimensional gel

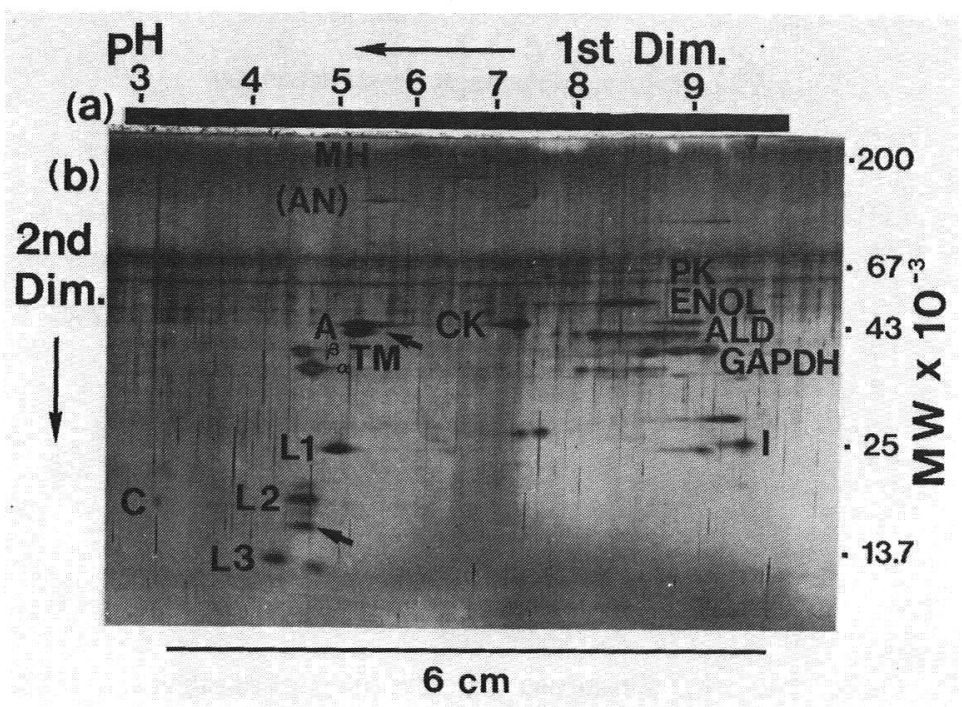

Fig. 3. Micro-two-dimensional gel electrophoresis of rabbit skeletal muscle (psoas) extract.

(a) A micro-agarose gel after the first-dimension isoelectric focusing of the muscle extract. About $0.5 \mu 1$ of the muscle extract diluted 10 times with the outer medium used for dialysis was charged onto the gel in a hematocrit tube, and isoelectric focusing was conducted for $2 \mathrm{~h}$ at $200 \mathrm{~V}$ and then for $2 \mathrm{~h}$ at $400 \mathrm{~V}$. (b) The second-dimension SDS-polyacrylamide gel electrophoresis with the micro-gel which was stained with silver stain. Arrows show additional spots of actin and myosin light chain. The experiment was conducted under otherwise the same conditions as in Fig. 2. 
electrophoresis with agarose gel in the first dimension can easily be carried out on both micro- and macro-scales which give us almost identical protein maps of wide ranges of isoelectric point and molecular weight.

By the micro-scale electrophoresis, pyruvate kinase, enolase and aldolase tended to form trailing lines rather than spots (Fig. 2 and 3). We can not attribute this tendency to the nonlinear $\mathrm{pH}$ gradient generated in the gel, since glyceroaldehyde-3-phosphate dehydrogenase was focused beautifully in the same $\mathrm{pH}$ range. A purified protein is generally focused in a narrow $\mathrm{pH}$ range, while the same protein is not focused when electrophoresed with other components like those contained in muscle extract. Probably there are some kinds of interactions between the components which interfere with free migration of components to their respective positions. Pyrophosphate in the sample solution was used to dissolve myosin heavy chain, but it seemed to be effective in dissolving other high molecular weight proteins around myosin heavy chain spot as well. Reduction of pyrophosphate concentration apparently reduced the amounts of these proteins and higher concentration of it disturbed the $\mathrm{pH}$ gradient. Therefore, the concentration must be kept the same in each electrophoresis to obtain reproducible results. In this work as in the previous one ${ }^{2)}$, we treated agarose gels with the denaturing solution in order to visualize protein bands after the first-dimension isoelectric focusing. The denaturation was useful to see the focusing pattern prior to the second-dimension electrophoresis. However, a prolonged treatment with the denaturant was found harmful to some proteins. For example, the longer the gel was immersed in the denaturing solution, the more amount of myosin heavy chain tended to be trapped on the top of separation gel in the second-dimension electrophoresis; aldorase formed blurred spots; tropomyosin formed aggregation in the higher molecular weight region. We have also found that albumin appeared as a diffuse spot after the denaturation (unpublished data). In conclusion, a shorter time of denaturation (within $1 \mathrm{~h}$ ) gives the best result as far as muscle proteins are concerned.

Two-dimensional SDS-polyacrylamide gel electrophoresis was introduced originally as the best method for analysis of whole protein constituents $^{1}$. But, we knew that it was still difficult to obtain whole spectrum of proteins on a single gel and that much improvement had to be made in dissolving whole proteins, in analyzing higher molecular weight proteins, and in stabilizing a wide $\mathrm{pH}$ range. Employment of thiourea and urea to dissolve the sample protein improved these points very much, and made it possible to carry out micro -scale two-dimensional electrophoresis with agarose gel in the first dimension.

We consider this micro-scale electrophoresis is suitable for the analysis of a limited amount of high molecular weight proteins with isoelectric points between $\mathrm{pH} 3.0$ to $\mathrm{pH}$ 9.5. Although the resolution as judged by Coomassie and silver stains is not as high as the macro-scale system, we think that this improved procedure for agarose gel preparation is applicable to a variety of experiments.

\section{要旨}

アガロースを 1 次元目に用いるミクロ 2 次元電気泳 動法を確立した．アガロースを 1 次元目に用いるとき， これが室温では固まりやすいためミクロ法を行うのは 困難であったが，これまでの $7 \mathrm{M}$ 尿素の代わりに $1 \mathrm{M}$ チオ尿素 $5 \mathrm{M}$ 尿素を用いると, 室温では固まらず, $4{ }^{\circ} \mathrm{C}$ で固化し，室温にもどしても固化したままにとどまる ことが判った。この方法をマクロとミクロで比較して みた結果, ほぼ同程度の分析が出来ることが判り，ア ガロースを 1 次元目に用いるミクロ 2 次元電気泳動法 が行えるようになった。

\section{REFERENCES}

1) O'Farrell, P. H. : J. Biol. Chem., $250: 4007$, 1975.

2) Hirabayashi, T. : Anal. Biochem., $117:$ 443, 
(120) The Physico-Chemical Biology

1981.

3 ) Yates, L. D. and Greaser, M. L.: J. Mol. Biol., $168:$ 123, 1983.

4) Laemmli, U. K. : Nature, $227: 680,1970$.

5 ) Merril, C. R., Goldman, D., Sedman, S. A. and Ebert, M. H. : Science, $211:$ 1437, 1981.
6) Hirabayashi, T., Tamura, R., Mitsui, I. and Watanabe, Y.: J. Biochem., 93 : 461, 1983.

7 ) Wong, J., Hutchison, S. B. and Liem, R. K. H. : J. Biol. Chem., 259 : 10867, 1984.

$8)$ Giometti, C. S., Anderson, N. G. and Anderson, N. N. : Clin. Chem., $25: 1877,1979$. 